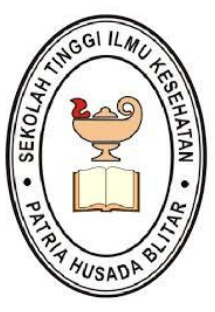

JNK

JURNAL NERS DAN KEBIDANAN (JOURNALOFNERS AND MIDWIFERY) http://jnk.phb.ac.id/index.php/jnk

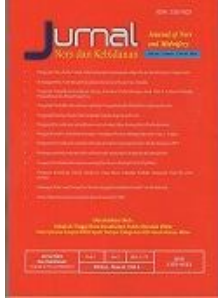

\title{
Pengaruh Program Pembentukan Kepribadian dan Kepemimpinan (P2KK) terhadap Soft Skill Mahasiswa
}

\section{Lilis Setyowati ${ }^{1}$, Nadia Mar'atu Sholihah ${ }^{2}$, Nur Aini ${ }^{3}$}

${ }^{1}$ Dosen Keperawatan, Fakultas Ilmu Kesehatan, Universitas Muhammadiyah Malang, Indonesia

${ }^{2,3}$ Mahasiswa Keperawatan, Fakultas Ilmu Kesehatan, Universitas Muhammadiyah Malang, Indonesia

Info Artikel Abstrak

\section{Sejarah Artikel:}

Diterima, 29/10/2019

Disetujui, 06/03/2020

Dipublikasi, 05/08/2020

\section{Kata Kunci:}

Program Pembentukan Kepribadian dan Kepemimpinan, Soft Skill, Mahasiswa
Program Pembentukan Kepribadian dan Kepemimpinan (P2KK) merupakan program pembentukan karakter yang bertujuan mengembangkan keterampilan soft skill mahasiswa. Sampai saat ini, evaluasi ketercapaian tujuan program masih belum diteliti. Penelitian ini bertujuan untuk mengetahui pengaruh P2KK terhadap soft skill mahasiswa FIKES Universitas Muhammadiyah Malang (UMM). Desain penelitian yang digunakan adalah pre-eksperimental one group pre-post test design. Pengambilan sampel pada penelitian ini menggunakan sampling kuota. Jumlah sampel yang digunakan sebanyak 100 mahasiswa FIKES Universitas Muhammadiyah Malang angkatan 2018 yang mengikuti $\mathrm{P} 2 \mathrm{KK}$ angkatan 24 dan 25. Pengumpulan data menggunakan kuesioner LEQ (Life Effectiveness Questionnaire) dengan analisa data menggunakan uji Wilcoxon. Kegiatan P2KK dilaksanakan selama 6 hari dan selama kegiatan tersebut mahasiswa harus tinggal di asrama. Soft skill mahasiswa FIKES Universitas Muhammadiyah Malang sebelum mengikuti P2KK 72\% memiliki kategori sedang dengan nilai rata-rata 140 dan soft skill setelah P2KK 76\% memiliki kategori sedang dengan nilai rata-rata 15. Berdasarkan hasil analisa data menggunakan uji Wilcoxon didapatkan hasil yang signifikan $(\mathrm{p}=0,00)$, artinya terdapat perbedaan soft skill sebelum dan setelah P2KK. Terdapat pengaruh P2KK terhadap soft skill mahasiswa FIKES Universitas Muhammadiyah Malang dengan metode pendekatan experiental learning yang dapat meningkatkan soft skill. Pengaruh yang paling signifikan terdapat pada atribut mengontrol emosi. Disarankan pihak UPT. P2KK untuk mengevaluasi metode kegiatan sehingga dapat meningkatkan atribut soft skill yang kurang. 
The Effect of Personality Development and Leadership Program (P2KK) On Student's Soft Skills

\section{Article Information}

\section{History Article:}

Received, 29/10/2019

Accepted, 06/03/2020

Published, 05/08/2020

\section{Keywords:}

The Personality Development and Leadership Program, Soft Skill, Student
Abstract

The Personality Development and Leadership Program (P2KK) is a character-building program to develop student skills to prepare them in the work requirements. The evaluation of the achievement of program objectives has not been studied before. This study aimed to determine the effect of P2KK on soft skills of the Faculty of Health Science (FIKES) students at the University of Muhammadiyah Malang (UMM). The study design used pre-experimental one group pre-post test design. The sampling technique used quota sampling technique. We included 100 students of Class 2018 of the FIKES UMM who participated in P2KK in 24 and 25 groups. We collected the Life Effectiveness Questionnaire (LEQ) and the Wilcoxon test was used to analyze the data. The soft skills of the students before taking $P 2 K K 72 \%$ had a moderate category with an average value of 140 and soft skills after $P 2 K K 76 \%$ had a moderate category with an average value of 15. Based on the results of data analysis using the Wilcoxon test, the result was significant $(p=0.00)$ indicating that the soft skills before and after P2KK were different. P2KK influenced the soft skills of FIKES UMM students by an experiential learning approach that able to improve their soft skills. The most significant influence is on the emotional control attribute. Suggested that the UPT P2KK to evaluate the method of activities so as to increase the attributes of soft skills that are lacking.

(C) 2020 Jurnal Ners dan Kebidanan

${ }^{\square}$ Correspondence Address:

Universitas Muhammadiyah Malang - East Java, Indonesia

P-ISSN : 2355-052X

Email: aini_anindya@yahoo.com

E-ISSN : 2548-3811

DOI: $10.26699 /$ jnk.v7i2.ART.p276-284

This is an Open Access article under the CC BY-SA license (http://creativecommons.org/licenses/by-sa/4.0/

\section{PENDAHULUAN}

Pendidikan yang ada di Indonesia belum optimal karena belum sepenuhnya diikuti dengan pendidikan karakter dan akhlak mulia, serta lebih menekankan pada dimensi hard skill daripada soft skill. Kebijakan yang diterapkan oleh Kemendikbud adalah pengembangan kurikulum pendidikan yang memberikan muatan soft skill sehingga diharapkann dapat meningkatkan akhlak mulia dan menumbuhkan karakter berbangsa dan bernegara (Kementrian Pendidikan dan Kebudayaan, 2013).

Pendidikan karakter saat ini menjadi salah satu solusi dalam mengatasi kemerosotan moral. Ditinjau dari sisi psikologis, karakter merupakan gambaran dari beberapa potensi yaitu Intellegency Quotient (IQ), Emotional Quotient (EQ), Spiritual Quotient (SQ), dan Adverse Quotient (AQ). Penelitian yang dilakukan lembaga Emotional Quality Inventory
(EQI) menyatakan bahwa kontribusi IQ (hard skill) dibandingkan dengan EQ (soft skill) hanya 20\% bagi kesuksesan seseorang. Haryati (2015) menyatakan, $85 \%$ keberhasilan di dunia kerja ditentukan oleh soft skill dan 15\% oleh hard skill (Rongraung, Somprach, Khanthap, \& Sitthisomjin, 2014).

Hasil Penelitian oleh Nurmaulidya (2013), soft skill peserta didik di SMA Negeri 6 Bandar Lampung masih kurang sehingga berdampak pada buruknya karakter yang terbentuk. Masih banyak pelanggaran-pelanggaran yang dilakukan siswa terhadap aturan sekolah. Rata-rata soft skill di SMK Muda Patria Kalasan juga rendah yaitu 40.38\% (Rismanto \& Munir, 2013). Evaluasi soft skill pada mahasiswa baru di Fakultas Teknologi Pertanian Universitas Udayana didapatkan data bahwa skor rata-rata soft skill 5,48 dan termasuk dalam kategori biasa yang mengindikasikan bahwa 
kualitas soft skill mahasiswa baru masih belum baik dan harus ditingkatkan (Arnata \& Surjoseputro, 2014).Hasil observasiyang dilakukan pada bulan Oktober 2018, pada 15 mahasiswa baru ilmu keperawatan yang belum mengikuti P2KK (Program Pembentukan Kepribadian dan Kepemimpinan) memilikisoft skillkurang dengan nilai terendah adalah aspek kepercayaan diri aspek kedisiplinan dan komunikasi.

Menurut Nurmaulidya (2013) faktor-faktor pembentuk perilaku dibagi menjadi dua yaitu faktor internal meliputi insting biologis, kebutuhan psikologis dan kebutuhan pemikiran dan faktor eksternal meliputi lingkungan keluarga, sosial, dan pendidikan. Terdapat dua faktor besar yang mempengaruhi kepribadian yaitu faktor internal dan eksternal. Faktor internal adalah faktor dari dalam diri yang merupakan faktor genetik, sedangkan faktor eksternal adalah faktor dari luar mulai dari lingkungan terkecil yaitu keluarga, tetangga sampai media massa seperti TV, internet, majalah dan lain lain (Chairilsyah, 2012).

Setiani \& Rasto (2016) menjelaskan bahwa soft skill dapat dibentuk melalui proses pembelajaran yang mampu menarik minat dan perhatian para pelajar, membangkitkan motivasi, prinsip individualitas dan menerapkan sistem peragaan dalam pengajaran. Data ini di dukung oleh penelitian $\mathrm{Hi}-$ dayati, et al (2015) yang menyatakan bahwa strategi pembelajaran, pengalaman organisasi, pelatihan pembentukan karekter, seminar, dan pendidikan informal juga dinilai berpengaruh terhadap pembentukan soft skill.

P2KK merupakan program pembentukan karakter yang di dalam muatannya terdapat materi keterampilan akademik, keterampilan sosial, kepemimpinan, ibadah dan keislaman juga terdapat pengenalan budaya di perguruan tinggi. Salah satu tujuan P2KK adalah mengembangkan keterampilan soft skill mahasiswa sesuai dengan kebutuhan kerja. Program ini merupakan upaya UMM dalam mengembangkan soft skill dan hard skill mahasiswa secara seimbang. Program yang telah berjalan sejak tahun 2004 ini mengalami beberapa perubahan dan penyempurnaan dalam desain kegiatannya. Evaluasi program terkait dengan fasilitas, trainer dan kegiatan oleh peserta P2KK sudah dilaksanakan sejak tahun 2017, namun evaluasi terhadap ketercapaian tujuan yaitu mengembangkan keterampilan soft skill mahasiswa sesuai dengan dunia kerja masih belum dilaksanakan oleh pihak UPT. P2KK maupun universitas. Oleh karena itu tujuan penelitian ini adalah mengetahui Pengaruh P2KK terhadap Soft Skill mahasiswa Fakultas Ilmu Kesehatan (FIKES) UMM".

\section{BAHAN DAN METODE}

Jenis penelitian pre-eksperimental dengan desainone group pre-post test. Pelaksanaan kegiatan P2KK bekerjasama dengan UPT. P2KK UMM. Populasi penelitian adalah mahasiswa FIKES angkatan 2018 yang belum mengikuti P2KK tahun 2018/2019 berjumlah 135 yang terbagi dalam 3 jurusan yaitu farmasi 52 mahasiswa, ilmu keperawatan 34 mahasiswa dan fisioterapi 49 mahasiswa. Sampel 100 mahasiswa yang dihitung dengan tabel Isaac dan Michael, yang diambil dengan teknik quota sampling.

Variabel independen adalah P2KK sedangkan variabel dependen adalah soft skill. Kegiatan P2KK dilaksanakan selama 6 hari dan selama kegiatan tersebut mahasiswa harus tinggal di asrama. Materi yang diberikan adalah: 1). Kepribadian, 2). Kepemimpinan, 3). KeterampilanSosial, 4). Keterampilan Akademik, 5). Budaya Perguruan Tinggi, dan 6). Keislaman

Instrumen soft skill menggunakan LEQ (Life Effectiveness Questionnaire) dibuat oleh James Neill, Herbert W. Marsh dan Garry E. Richard (2007), yang telah diuji validitas dan reliabilitas, dan nilai reliabilitas Cronbach's Alpha 0,942.Pemberian instrumen dilakukan $2 \mathrm{x}$ yaitu pada hari pertama P2KK (mengukur pre test) dan 18 hari setelah P2KK (mengukur post test), karena didasarkan penelitian yang dilakukan Lally dkk tahun 2010 yang menyatakan bahwa waktu pembentukan perilaku tiap orang bervariasiantara 18 hingga 245 hari. Analisis data menggunakan uji wilcoxon.Dilakukan pula pengukuran Effect Size (ES) untuk mengukur besarnya pengaruh dari sebuah perlakuan. ES dapat digunakan sebagai korelasi antara klasifikasi variabel independen dengan skor individu pada variabel dependen.

\section{HASIL PENELITIAN}

\section{Gambaran Karakteristik Responden}

Karakteristik mahasiswa baru FIKES UMM yang mengikuti kegiatan P2KK dijelaskan dalam Tabel 1.

Berdasarkan Tabel 1, terdapat perbedaan ratarata soft skill antara antara ketiga jurusan sebelum $\mathrm{P} 2 \mathrm{KK}$. 
Tabel 1 Karakteristik Mahasiswa FIKES UMM Yang Mengikuti P2KK Bulan Januari 2019

\begin{tabular}{|c|c|c|c|c|c|}
\hline \multirow{2}{*}{ No } & \multirow{2}{*}{ Karakteristik } & \multicolumn{2}{|c|}{ Sampel } & \multicolumn{2}{|c|}{ Rata-Rata Soft Skill } \\
\hline & & f & $(\%)$ & Pre & Post \\
\hline \multirow[t]{4}{*}{1} & Jurusan & & & & \\
\hline & Program Studi Ilmu Keperawatan & 22 & 22 & 134 & 149 \\
\hline & Farmasi & 41 & 41 & 141 & 151 \\
\hline & Fisioterapi & 37 & 37 & 141 & 153 \\
\hline \multirow[t]{3}{*}{2} & Jenis Kelamin & & & & \\
\hline & Laki-Laki & 25 & 25 & 140 & 153 \\
\hline & Perempuan & 75 & 75 & 139 & 151 \\
\hline \multirow[t]{3}{*}{3} & Usia (tahun) & & & & \\
\hline & $17-19$ & 95 & 95 & 140 & 151 \\
\hline & $20-22$ & 5 & 5 & 124 & 155 \\
\hline \multirow[t]{3}{*}{4} & Pengalaman Organisasi selama Kuliah & & & & \\
\hline & Ada & 53 & 53 & 142 & 157 \\
\hline & Tidak ada & 47 & 47 & 136 & 145 \\
\hline \multirow[t]{3}{*}{5} & Pengalaman Organisasi selama SMA & & & & \\
\hline & Ada & 85 & 85 & 141 & 153 \\
\hline & Tidak ada & 15 & 15 & 131 & 142 \\
\hline \multirow[t]{4}{*}{6} & Pendidikan Terakhir & & & & \\
\hline & SMA & 79 & 79 & 140 & 151 \\
\hline & SMK & 13 & 13 & 140 & 149 \\
\hline & Aliyah & 8 & 8 & 135 & 155 \\
\hline \multirow[t]{3}{*}{7} & Lingkungan Asal Daerah & & & & \\
\hline & Desa & 56 & 56 & 138 & 154 \\
\hline & Perumahan/Kota & 44 & 44 & 142 & 148 \\
\hline \multirow[t]{5}{*}{8} & Pendapatan Orang Tua perbulan & & & & \\
\hline & $<1.000 .000$ & 3 & 3 & 128 & 165 \\
\hline & $1.000 .000-5.000 .000$ & 67 & 67 & 140 & 149 \\
\hline & $5.000 .000-10.000 .000$ & 20 & 20 & 138 & 151 \\
\hline & $>10.000 .000$ & 10 & 10 & 143 & 158 \\
\hline
\end{tabular}

Soft Skill Mahasiswa FIKES sebelum dan setelah P2KK

Tabel 2 Soft Skill Mahasiswa FIKES UMM Sebelum dan Sesudah Kegiatan P2KK Bulan Januari 2019

\begin{tabular}{lcccc}
\hline Variabel & Mean & Min & Max & SD \\
\hline Soft Skill sebelum P2KK & 140 & 56 & 184 & 21 \\
Soft Skill setelah P2KK & 151 & 88 & 192 & 18 \\
\hline
\end{tabular}

Tabel 3 Kategori Soft Skill Mahasiswa FIKES UMM Sebelum dan Sesudah Kegiatan P2KK Bulan Januari 2019

\begin{tabular}{lccc}
\hline Kategori Soft Skill & Pre & Pre & Hasil uji wilcoxon \\
\hline Tinggi & $11(11 \%)$ & $13(13 \%)$ & $\mathrm{P}=0,00$ \\
Sedang & $72(72 \%)$ & $76(76 \%)$ & \\
Rendah & $17(17 \%)$ & $11(11 \%)$ & \\
\hline Total & $100(100 \%)$ & $100(100 \%)$ & \\
\hline
\end{tabular}


Berdasarkan Tbel 2, diketahui data hasil penelitian nilai soft skill mahasiswa FIKES sebelum P2KK memiliki rata-rata 140 dan setelah P2KK menjadi 15. Sedangkan pada Tabel 3, soft skill mahasiswa FIKES sebelum P2KK memiliki kategori sedang yaitu sebesar 72\% dan setelah P2KK adalah kategori sedang sebesar $76 \%$. Nilai $p=0,00<\alpha 0,05$ artinya terdapat pengaruh P2KK terhadap soft skill mahasiswa FIKES UMM.

Atribut Soft Skill Mahasiswa FIKES UMM Sebelum dan Setelah P2KK

Tabel 4 Soft Skill Mahasiswa FIKES UMM Berdasarkan Atribut Soft Skill Bulan Januari 2019

\begin{tabular}{lccc}
\hline Atribut Soft Skill & Pre (M \&SD) & Post (M \&SD) & ES \\
\hline Manajemen waktu & $5,48(0,22)$ & $6,18(0,05)$ & 4,4 \\
Kemampuan sosial & $5,81(0,41)$ & $6,23(0,29)$ & 1,2 \\
Motivasi berprestasi & $6,57(0,25)$ & $6,92(0,22)$ & 1,5 \\
Pemikiran fleksibel & $5,99(0,18)$ & $6,52(0,23)$ & 2,6 \\
Kepemimpinan & $5,23(0,45)$ & $5,80(0,34)$ & 1,4 \\
Mengontrol emosi & $5,47(0,16)$ & $6,06(0,05)$ & 5,1 \\
Berinisiatif & $5,76(0,21)$ & $6,16(0,22)$ & 1,8 \\
Kepercayaan diri & $6,20(0,18)$ & $6,54(0,17)$ & 1,9 \\
\hline
\end{tabular}

Berdasarkan Tabel 4, diketahui bahwa perbandingan rata-rata soft skill menurut 8 atribut didapatkan bahwa rata-rata soft skill setelahP2KK lebih tinggi dibandingkan sebelum P2KK.

\section{PEMBAHASAN}

\section{Karakteristik Mahasiswa FIKES UMM Yang Mengikuti P2KK Bulan Januari 2019}

Jurusan ilmu keperawatan memiliki rata-rata soft skill yang lebih kecil dibandingan jurusan farmasi dan fisioterapi yang memiliki nilai rata-rata sama. Perbedaan ini kemungkinan didapatkan karena perbedaan sosiodemografi individu sebagaimana pada tabel di atas. Rata-rata soft skill setelah P2KK meningkat cukup baik.

Hasil penelitian ini menunjukkan bahwa ratarata soft skill laki-laki lebih besardaripada perempuan sebelum dan setelah $\mathrm{P} 2 \mathrm{KK}$, namun rata-rata ini tidak berbeda jauh. Hasil ini sesuai dengan penelitian yang dilakukan oleh Hirsch (2017) yang menyatakan jenis kelamin tidak signifikan terhadap tingkat soft skill seseorang. Berdasarkan penelitian Ravindran dan Bandara (2015) menyatakan bahwa tingkatan soft skill berdasarkan jenis kelamin memiliki hasil yang bervariasi antara perempuan dan lakilaki. Beberapa soft skill lebih besar dimiliki lakilaki yaitu kepercayaan diri, mengontrol emosi, memahami situasi, memaafkan dan melupakan kesalahan orang lain, kepemimpinan, berbicara di depan umum, negosiasi, membuat jaringan dengan orang-orang dan lain lain selain itu beberapa soft skill lebih besar dimiliki oleh perempuan yaitu kesadaran diri, mengatasi situsi buruk, komunikasi, kerjasama tim dan lain lain.

Hasil penelitian ini menunjukkan bahwa ratarata soft skill sebelum P2KK lebih besar pada usia 17-19 dan setelah P2KK lebih besar pada usia 2022 tahun. Faktor usia diyakini sebagai salah satu faktor terbentuknya soft skill. Sesuai dengan penelitian tentang faktor- faktor pembentuk soft skill yang dilakukan oleh Ravindran dan Bandara(2015) bahwa terdapat peningkatan soft skill seiring berjalannya usia. Pengalamanhidup lebih banyak didapatkan oleh orang yang lebih tua akan membentuk soft skill semakin baik.

Sebagian besar responden memiliki pengalaman organisasi selama SMA dan di perkuliahan. Penelitian ini menunjukkan rata-rata yang lebih tinggi dan cukup jauh pada responden yang berorganisasi sebelum dan setelah P2KK. Pengalaman organisasi akan mempengaruhi kehidupan seseorang. Organisasi diyakini sebagai sebuah sarana pengembangan diri, karena didalamnya seseorang akan dilatih untuk berproses dalam pembentukan karakter dan pendewasaan dalam menghadapi berbagai permasalahan yang ada (Hidayati, et al, 2015). Hal ini sesuai dengan hasil penelitian Yulianto tahun 2015 dalam penelitiannya menyatakan bahwa terdapat pengaruh positif dan signifikan keaktifan siswa berorganisasi terhadap peningkatan soft skil dengan harga koefi- 
sien korelasi $r=0,493$. Hasil penelitian ini juga diperkuat dengan Suranto \& Rusdianti (2018), bahwa pengalaman berorganisasai dapat membentuk soft skill mahasiswa dan manfaat yang didapatkan diorganisasi yaitu diantaranya membantu dan meningkatkan leadership, communication skill, teamwork, memperluas jaringan atau networking, problem solving dan manajemen konflik.

Hasil penelitian ini menunjukkan bahwa pendidikan SMA dan SMK memiliki rata-rata soft skill yang sama dan lebih tinggi dibandingkann Aliyah dan setelah P2KK. soft skill yang paling besar pada lulusan Aliyah namun tidak berbeda jauh. Pembelajaran adalah proses perubahan perilaku pada seseorang sebagai hasil dari pengalaman maupun pelatihan. Kegiatan pembelajaran di sekolah dapat mengembangkan soft skill seseorang. Menurut Rasmita, dkk (2009) jikapendidikan yang diterima seseorang semakin baik maka akan semakin baik juga soft skill yang dimiliki. Pendidikan yang terencana akan meningkatkan keterampilan, termasuk juga proses belajar. Penelitian sebelumnya oleh Rismanto \& (2013) menyatakan bahwa rata-rata soft skill di SMK Muda Patria Kalasan masih rendah yaitu sebesar $40.38 \%$. Berbeda dengan hasil ini, penelitian lain yang dilakukan oleh Zammi dan Khoiriyyah (2018) kepada siswa SMK menyatakan bahwa persentaserata-rata soft skill siswa sebesar $52,56 \%$ dengan kategori cukup kemudian meningkat menjadi kategori tinggi dengan persentase $81,88 \%$ setelah implementasi pembelajaran chemoenterpreunership.

Responden yang tinggal di lingkungan perumahan atau kota memiliki rata-rata soft skill yang lebih besar sebelum P2KK dibandingkan responden yang tinggal di desa. Menurut Rasmita, dkk (2009) lingkungan mempengaruhi terbentuknya soft skill seseorang. Lingkungan yang kondusif dan baik akan menyebabkan munculnya berbagai soft skill. Hal ini dikarenakan seseorang cenderung akan meniru apa yang terjadi disekitarnya sehingga mempengaruhi sikap dan karakter seseorang. Lingkungan pedesaan dan perkotaan memiliki ciri yang berbeda. Menurut Hidayah (2011) ciri-ciri menonjol pada masyarakat pedesaan adalah kehidupan masyarakatnya agamis,pembagian kerja tidak nyata, dan jalan pemikiran orang desa lebih bersifat sosial dibandingkan orang kota yang lebih bersifat ekonomis dan rasional. Ciri yang berbeda antara masyarakat desa dan kota tentunya akan berpengaruh terhadap soft skill yang dimiliki seseorang.
Sebelum P2KK rata-rata soft skill paling besar dimiliki oleh responden yang pendapatan orang tuanya paling tinggi yaitu lebih dari sepuluh juta dan setelah P2KK rata-rata soft skill lebih besar pada responden yang pendapatan orang tuanya dibawah satu juta. Perbedaan rata-rata antara pendapatan dibawah satu juta dan diatas sepuluh juta tidak jauh. Pendapatan orang tua pada penelitian ini dikaitkan dengan fasilitas dan teknologi yang dimiliki seseorang khususnya mahasiswa. Fasilitas dan teknologi memiliki hubungan yang positif terhadap pembentukan soft skill. Fasilitas dan teknologi yang memadai dapat membuat seseorang mampu mengembangkan diri sehingga dapat membentuk soft skill (Ravindran \& Bandara, 2015).

\section{Soft Skill Mahasiswa FIKES sebelum dan setelah P2KK}

Rata-rata soft skill yang paling rendah sebelum dan setelah P2KK yaitu kepemimpinan dengan nilai sebelum P2KK 5,23 dan setelah P2KK 5,80. Soft skill yang paling tinggi adalah motivasi untuk berprestasi dengan nilai sebelum P2KK 6,57 dan setelah P2KK 6,92. Perubahan soft skill paling kecil sebelum dan setelah P2KK adalah kemampuan sosial dengan nilai ES sebesar 1,2 dan yang terbesar adalah pada atribut mengontrol emosi dengan nilai ES sebesar 5,1. Berikut penjelasan dari masing-masing atribut soft skill: 1). Manajemen Waktu: mengidentifikasi sejauh mana seseorang dapat memanfaatkan dan mengatur waktu secara optimal. Selama 6 hari peserta dilatih agar selalu tepat waktu dalam semua kegiatan dan akan diberikan sanksi apabila telat. Peserta juga mendapatkan materi dan simulasi tentang manajemen waktu sehingga berpengaruh pada peningkatan soft skill. 2). Kemampuan Sosial: adalah tingkat kepercayaan dan persepsi diri terhadap kemampuan dalam berinteraksi sosial, meliputi presepsi tentang kehidupan sosial yang sukses dan kemampuan berkomunikasi. Peningkatan soft skillsetelah P2KK karena banyaknya interaksi sosial selama kegiatan berlangsung. Peserta tinggal sekamar bersama 9-10 orang dan mengikuti kegiatan di kelas bersama peserta lain yang berjumlah 25-34 orang yang terdiri dari jurusan dan daerah asal yang berbeda mulai jam 3 pagi sampai dengan setengah 10 malam. 3). Motivasi Berprestasi: Merupakan soft skillyang paling tinggi yang dimiliki mahasiswa FIKES. Soft skill ini menginterpretasikan bahwa mahasiswa memiliki motivasi yang tinggi untuk meraih prestasi dan 
penghargaan sehingga melakukan upaya dan tindakan untuk mencapainya. Pembelajaran mahasiswa kesehatan yang lebih menekankan pada hafalan dengan materi yang banyak menyebabkan mahasiswa termotivasi untuk terus belajar dan berprestasi. Setelah P2KK soft skill ini meningkat, dikarenakan peserta dilibatkan secara aktif dan sistem pembelajaran yang diterapkan dapat dipahami dengan mudah. 4).Pemikiran yang Fleksibel: menginterpertasikan sejauh mana seseorang dapat menyesuaikan pemikirannyadan menerima informasi baru dari pemikiran yang berbeda. Latar belakang dan karakteristik mahasiswa yang berbeda dapat menambah wawasan dan pergaulan peserta yang lebih luas sehingga mengasah pola pikir menjadi lebih fleksibel. 5). Kepemimpinan: Soft skill ini memiliki rata-rata paling rendah. Kepemimpinan yang rendah menunjukkan bahwa mahasiswa masih kurang dalam memimpin orang lain secara efektif ketika melaksanakan suatu tugas dan dalam dapat melakukannya masih kurang produktif. Hasil ini serupa dengan penelitian yang dilakukan oleh Hartiti \& Ernawati (2016), soft skill terendah pada mahasiswa keperawatan adalah kemampuan memimpin dan berfikir kritis sebesar 24,6\%. Selama pelatihan peserta tidak dibedakan antara satu dan yang lainnya. Semua peserta diberikan kesempatan untuk menjadi pemimpin baik laki-laki maupun perempuan sehingga hal ini diyakini dapat menigkatkan soft skill kepemimpinan 6). Mengontrol Emosi: menginterpretasikan sejauh mana seseorang bisa mengendalikan atau mengontrol emosi ketika ia dihadapkan dengan situasi yang dapat membuat stres. Selama P2KK peserta diawasi selama 24 jam dan diwajibkan disiplin terhadap peraturan yang berlaku selama kegiatan berlangsung. Kegiatan yang cukup padat yang dilaksanakan bersama banyak peserta lain diyakini meningkatkan kemampuan mengontrol emosi. 7). Berinisiatif : mengidentifikasi sejauh mana seseorang memulai suatu tindakan dalam situasi baru. Lingkungan P2KK merupakan lingkungan yang baru bagi peserta, di dalam kelas peserta diberikan stimulus oleh fasilitator untuk aktif selama pelatihan dan masing-masing individu diberikan kesempatan untuk mengutarakan pendapatnya. Selain diberikan materi, peserta juga diberikan simulasi, games, lomba yel-yel dan outbond yang akan meningkatkan kemampuan peserta dalam berinisiatif. 8).Kepercayaan Diri: merupakan kepercayaan yang dimiliki individu di dalam dirinya terhadap kemampuan dan keberhasilan atas tindakan yang ia lakukan. Lingkungan yang mendukung selama kegiatan, pemberian stimulus dari fasilitator kepada peserta untuk aktif dan mengapresiasi secara positif setiap jawaban, tindakan atau keputusan yang dibuat oleh peserta, pemberian motivasi dan materi tentang mengenal diri sendiri sehingga lebih percaya diri, pelatihan speaking skill dan pembagian kelompok menyebabkan peningkatkan kepercayaan diri peserta.

\section{Atribut Soft Skill Mahasiswa FIKES UMM Sebelum dan Setelah P2KK}

Program pembentukan karakter dapat menjadi langkah awal dalam membentuk individu yang prima sehingga diharapkan mampu memiliki soft skill yang baik. Proses pembentukan karakter tidak secara langsung memberikan stimulus terhadap pengembangan soft skill seseorang sehingga masih dibutuhkan suatu proses yang panjang agar individu mempunyai soft skill yang baik dan memiliki mental yang stabil dalam menghadapi tantangan hidup dimasa depan. Karakteristik dari program pembentukan kepemimpinan yang efektif menurut Cansoy (2017) adalah: peserta harus diajarkan pengetahuan dan keterampilan; peserta memahami nilai-nilai sosial ; peserta harus dibantu meningkatkan kepemimpinan dan kelebihan yangdimiliki ; peserta harus didorong untuk mengembangkan etika, nilai-nilai dan pikiran yang etis, berpartisipasi dalam kerjasama tim, memiliki rasa hormat, kepercayaan dan harapan; peserta didukung untuk menghormati perbedaan; pembelajaran berbasis pengalaman (experiental learning); meningkatkan kesadaran peserta untuk membantu orang lain; program harus memberikan peluang untuk mengevaluasi pemikiran pribadi dan menciptakan pembelajaran secara kolaboratif maupun pribadi; ketika peserta melakukan pembelajaran harus melibatkan konsultan, panutan/role model dan orang dewasa.

Program P2KK secara umum memiliki banyak kesamaan yang sesuai dengan karakteristik dari program pembentukankepemimpinan yang efektif. Metode dan materi yang disampaikan disesuaikan dengan tujuan dan target yang akan dicapai. Pendekatan yang digunakan adalahexperiental learning, sering disebut juga sebagai "learning by doing"yaitu sebuah proses pembelajaran yang dilakukan dengan memberikan suatu pengalaman yang disengaja, terkait dengan informasi yang hendak diajarkan. Pendekatan ini fokus pada apa yang yang akan dipelajari oleh seseorang, hal itu 
akan mengaktifkan pembelajaran secara kognitif, emosional dan akan merubah perilaku seseuai dengan keterampilan yang diinginkan (Cunha, 2016).

Hasil dari penelitian ini sesuai dengan penelitian yang dilakukan oleh Cansoy (2017) yang dilakukan di Fakultas Ekonomi Universitas Karabik, Turki. Pelatihan yang dilakukan menggunakan experiental learning kepada 20 mahasiswa selama 1-1,5 jamperminggu selama 10 minggu memiliki hasil bahwa leadership skills development program di universitas efektif untuk meningkatkan soft skill karena secara signifikan meningkatkan keinginan untuk mencapai tujuan, keterampilan komunikasi, keterampilan kelompok, kemampuan memecahkan masalah, kemampuan dalam pengambilan keputusan, kesadaran akan tanggung jawab, kesadaran untuk mempercaya dan dipercaya, kesadaran kepemimpinan dan kesadaran emosional. Pembentukan soft skill membutuhkan waktu yang cukup panjang, bisa terbentuk ketika mahasiswa menempuh proses pendidikan minimal 3,5 bulan. Sehingga pihak Universitas khususnya Program Studi memiliki andil besar dalam membentuk soft skill mahasiswa melalui sistem pembelajaran yang seimbang antara soft skill dan hard skill.

\section{KESIMPULAN}

Soft skill mahasiswa FIKES UMM sebelum mengikuti P2KK sebagian besar memiliki kategori sedang. Rata-rata soft skill yang paling rendah sebelum dan setelah P2KK yaitu kepemimpinan dan soft skill yang paling tinggi adalah motivasi untuk berprestasi. Hasil uji statistik, terdapat pengaruh P2KK terhadap soft skill mahasiswa FIKES UMM.

\section{SARAN}

Diharapkan mahasiswa dapat meningkatkan soft skilldengan mengikuti berbagai kegiatan yang ada di Universitas, mengingat pentingnya peranan soft skill khususnya bagi tenaga kesehatan. Program studi dan UPT P2KK perlu mendesain sistem pembelajaran yang menerapkan keseimbangan antara soft skill dan hard skill,serta melakukan evaluasi metode kegiatan P2KK sehingga pdapat meningkatkan soft skill yang masih kurang.

\section{DAFTAR PUSTAKA}

Aly, A. (2017). Pengembangan Pembelajaran Karakter Berbasis Soft Skill Di Perguruan Tinggi. Ishraqi, l(1), 40-51.
Arnata, I. W., \& Surjoseputro, S. (2014). Evaluasi Soft Skills dalam Pembelajaran Mahasiswa Baru di Fakultas Teknologi Pertanian Universitas Udayana. Jurnal Pendidikan Dan Pembelajaran, 21(1), 1-9.

Cansoy, R. (2017). The Effectiveness Of Leadership Skills Development Program For University The Effectiveness Of Leadership Skills Development Program For University Students. History Culture And Art Research, 6(3), 65-87. Https://Doi.Org/ 10.7596/Taksad.V6i3.899

Chairilsyah, D. (2012). Pembentukan Kepribadian Positif Anak Sejak Usia Dini. Educhild, 1(1), 1-7.

Cunha, I. F. X. Da. (2016). The Efficacy Of 1-Day Soft Skills Training On Master Students ' Performance.

Hartiti, T., \& Ernawati. (2016). Gambaran Softskill Mahasiswa Sarjana Perawat Di FIKKES Universtas Muhammadiyah Semarang. RAKERNAS AIPKEMA 2016 "Temu Ilmiah Hasil Penelitian dan Pengabdian Masyarakat".

Haryati, S. (2015). Upaya Meningkatkan Soft Skill Mahasiswa Di Perguruan Tinggi. Seminar Ilmiah Semesteran Korpri Sub Unit Kopertis Wilayah VI Jawa Tengah, 1(2), 66-75. Retrieved from http:// lib.untidar.ac.id/wp-content/uploads/2017/01/ upaya-peningkatan-soft-skill-mhs-PT.pdf.

Hidayati, U., Susena, Mardinawati, \& Noor, A. (2015). Faktor-Faktor Yang Mempengaruhi Pengembangan Soft Skill (Soft Competency) Mahasiswa Jurusan Akuntansi Polines. Prosiding Sentrinov, 001, 2477-2097. https://doi.org/10.13140/RG.2.2.30630. 32324.

Hidayah, N. (2011). Kesiapan Psikologis Masyarakat Pedesaan Dan Perkotaan Menghadapi Diversifikasi Pangan Pokok. Humanitas, VIII(1), 88-104.

Hirsch, R. G. A. (2017). Gender Differences In The Performance Of Black High School Students On Job Interviews. Thesis, 1-42.

Kementrian Pendidikan dan Kebudayaan. (2013). Rencana Strategis Kementrian Pendidikan dan Kebudayaan 2010-2014, 1-6. https://doi.org/10.1017/CBO9781107 415324.004

Neill, J. (2007). Life Effectiveness Questionnaire: A Research Tool for Measuring Personal Change. Retrieved November 11, 2018, from http:// wilderdom.com/leq.html

Nurmaulidya, E. (2013). Kegiatan Ekstra Kurikuler Dan Pembentukan Soft Skill Peserta Didik di SMA Negeri 6 Bandar Lampung. Tesis, 0-11.

Rasmita, F., Elfindri, Wello, M. B., \& Rumengan, J. (2009). Pintar Soft Skills Membentuk Pribadi Unggul. (J. F. Rezky, Ed.). Bandouse Media.

Ravindran, K., \& Bandara. (2015). Factors Affecting Acquisition Of Soft Skills And The Level Of Soft Skills Among University Undergraduates (With Special Reference To Management Students Of Rajarata University Of Sri Lanka ). International 
Research Symposium Rajarata University Of Sri Lanka, 538-545.

Rismanto, H., \& Munir, M. (2013). Pengembangan Soft Skill Siswa Melalui Metode Cooperative Learning Tipe Jigsaw. http ://eprints.uny.ac.id/eprint/10451

Rongraung, S., Somprach, K., Khanthap, J., \& Sitthisomjin, J. (2014). Soft Skills for Private basic Education Schools in Thailand. Procedia - Social and Behavioral Sciences, 112, 956-961. https://doi.org/ 10.1016/j.sbspro.2014.01.1254
Setiani, F., \& Rasto. (2016). Mengembangkan Soft Skill Siswa Melalui Proses Pembelajaran. Jurnal Pendidikan Manajemen Perkantoran, 1(1), 170 176.

Suranto, \& Rusdianti, F. (2018). Pengalaman Berorganisasi Dalam Membentuk Soft Skill Mahasiswa. Pendidikan Dan Ilmu Sosial, 28(1), 58-65.

Zammi, M., \& Khoiriyyah, K. (2018). Analisis Kemampuan Soft Skills Siswa Kelas XI SMK Futuhiyyah Mranggen Demak, 08(2), 41-51. 